\title{
DEVELOPING SIMPLE PRESENT TENSE MASTERY IN WRITING DESCRIPTIVE TEXT AT THE FIRST SEMESTER STUDENTS OF STISIP PERSADA BUNDA PEKANBARU
}

\author{
Lia Diana \\ Akademi Bahasa Asing (ABA) Persada Bunda Pekanbaru \\ E-mail: liadiana12@gmail.com
}

\begin{abstract}
The simple present tense is the most basic tense that should be mastered by the first semester students of STISIP Persada Bunda Pekanbaru. Moreover, descriptive text is one of the text types which use the present tense. Descriptive text is used by the researcher as the text that let the students apply their ability in using the present tense. However, most students still face difficulties in using present tense in writing descriptive text. Thus, the researcher conducted the study entitled "Developing Students Simple Present Tense Mastery in Writing Descriptive Text at The First Semester Students of STISIP Persada Bunda Pekanbaru." This research aimed to identify the most dominant students' errors and to describe the factors causing students' errors in using present tense in writing descriptive text first semester students of STISIP Persada Bunda Pekanbaru. The study was used mixed methodology as the research method. The population were the first semester students of STISIP Persada Bunda Pekanbaru. In collecting the data, the researcher used the students' writing products in using present tense in writing descriptive text and the questionnaire. The study was showed two points; through the students' writing products would result in the students' errors and the questionnaire would show the factors causing students' errors in using present tense in writing descriptive text. Based on the research findings showed that the most dominant students' errors were misformation errors with 56 items $(62,92 \%)$. Moreover, based on the questionnaire could be concluded that the factors causing the students' errors in using the present tense in writing descriptive text were interlingual transfer and intralingual interference.
\end{abstract}

Keywords: Developing, present tense, descriptive text.

\begin{abstract}
Abstrak
Simple Present Tense merupakan pengetahuan dasar yang harus dikuasai oleh mahasiswa semester pertama di STISIP Persada Bunda Pekanbaru. Terlebih lagi, Teks Deskriptif adalah salah satu jenis teks yang menggunakan simple present tense dalam penggunaaan kalimatnya. Teks deskriptif dipilih oleh peneliti sebagai teks yang memudahkan siswa dalam menggunakannya. Namun, pada kenyataannya sebagian siswa masih menghadapi kesulitan dalam mennggunakan simple present tense untuk menulis deskriptif teks. Oleh sebab itu, peneliti melakukan riset yang berjudul "Developing Students Simple Present Tense Mastery in Writing Descriptive Text at The First Semester Students of STISIP Persada Bunda Pekanbaru." Tujuan dari penelitian ini adalah untuk mengetahui
\end{abstract}


seberapa dominannya kesalahan-kesalahan siswa dalam membuat deskriptif teks dan untuk menjabarkan faktor-faktor apa saja yang menyebabkan siswa kesulitan dalam menggunakan simple prseent tense ketika menulis deskriptif teks. Penelitian ini menggunakan pendekatan kualitatif dan kuantitaif. Partisipan dari peneltian ini adalah seluruh mahasiswa semester pertama jurusan Ilmu Komunikasi STISIP Persada Bunda Pekanbaru. Dalam mengumpulkan data, peneliti menggunakan hasil test yang dibuat mahasiswa untuk mengetahui sejauh mana kemampuan mahasiswa sehingga dapat diketahui kesalahan-kesaahan yang dibuat dan hasil kuesioner menunjukkan faktor-faktor yang menyebabkan mahasiswa mendapatkan kesulitan dalam membuat deskriptif teks. Berdasarkan dari penemuan penelitian ini menunjukkan bahwa sebagian kesulitann ataupun kesalahan yang dihadapi siswa bersumber dari misformation dengan jumlah 56 item $(62,92 \%)$. Juga, berdasarkan hasil dari kuesioner menunjukkan bahwa faktorfaktor yang menyebab kesulitan mahasiswa dalam menggunakan simple present tense untuk membuat deskriptif teks adalah interlingual transfer and intralingual interference.

Kata kunci: mengembangkan, kalimat present, deskriptif teks

\section{INTRODUCTION}

English is one of some international languages which is used by most people around the world. In a global era, people are expected to master English so that they can communicate with other people who live in other countries. As a tool of international communication, it should be learned by people who live in a country which uses English as a foreign language, including Indonesia. To support Indonesian people in order to be able to communicate with other people around the globe, the Indonesian government incorporates English into its educational curriculum as one of its compulsory subjects, starting from junior high school. Hence, it is hoped that there will be an excellent chance for Indonesian learners to improve their English communication competence.

Teaching English in Indonesia is focused on the ability of student's communication. The communication can be in oral and written forms. The learners should be capable of the four language skill (Depdiknas, 2006: 6). One of the skills that must be learned is writing. According to Byrne (1997:1), writing is producing a sequence of sentences arranged in a particular order and linked together in 
specific ways. Then, according to Admin (2009:16 ) that based on generic structure and language feature dominantly used, there are some types of text. They are report, analytical exposition, narrative, procedure, recount, spoof, anecdote, discussion, description, explanation, review, hortatory exposition, news item. In the teaching of writing skill, a descriptive text is popularly known as a descriptive paragraph. The students are trained to describe a particular object in a written language by developing one main idea as a Topic Sentence. So, it will be quite easy for them producing the simple text.

In this study, the writer is interested in researching descriptive text as one of the types of genre implemented in teaching writing. Descriptive text is a text which describes what a person or a thing is like. The main aim of descriptive text is to inform about the thing to be described. So, it provides generalized information on facts, qualities and characteristics about the object under consideration to get a systematic, accurate and almost photographic description. This type of texts are just straight facts and do not give the reader any ideas about the feelings or opinions of the author. The descriptive text has structure as below: (1) Identification; identifying the phenomenon to be described. (2) Description; describing the phenomenon in parts, qualities, and characteristics.

One of the text types which uses present tense is descriptive text because the writer describes something still alive, and this tense also one of the language characteristics in writing descriptive text (Noprianto, 2017). Thus, there is a connection between simple present tense and descriptive text. Due to the function of the simple present tense is not only used for talking about the general truth but also for describing people or things in a conventional way. As we know, the descriptive text that includes in Indonesia curriculum. It is used to describe something as a place, person, house, and so on. It includes a specific description of the thing or human being.

The reasons in choosing the first semester of STISIP Persada Bunda Pekanbaru causes the 
researcher found that when they try to express their ideas or feelings in writing, some errors will be found there. So, the researcher wants to know their most dominant errors and the factors causing students' errors in their writing. The errors happened when the learners did not learn something again and again (Norrish, 1983). Thus, the learners should learn something consistently in order to decrease their errors, particularly in writing descriptive text. The errors produced the wrong utterance or written that they would not be able to do self-corrected. Also, errors occurred when the learners were unable to use the language correctly based on structural grammar and is caused by the learners' inadequate knowledge of target language.

Meanwhile, the mistake happened when the learners were unable to perform what they had already known or learned, but they knew the correct item and could make the correction (Muhsin, 2016). Hence, the role of the teacher is a crucial need in this case. So, the teacher should focus on teaching present tense and let them practice.
In addition, the researcher considers that the students still require more knowledge in applying the simple present tense into their writing, particularly in writing a descriptive text, since many of errors will be found in it. Based on the reasons above, the researcher is interested in conducting research entitled "Developing Students' Simple Present Tense Mastery in Writing Descriptive Text".

In learning English as a foreign language, there is a component called grammar. When we learned grammar, the tense will automatically correlate. Tense means time. However, it should be pointed out that time to action is a concept that exists in the mind of the speaker, reader, or listener. Tense, in actual usage, refers consistently only to grammatical forms. Often tense and time do not correspond at all. It means that tense is the linguistic indication of the time of an action. Tense established a relation: it indicates the time of an event for the moment of speaking, reading, or listening. 
Tense is one of the critical parts of the structure in English. In learning English, the teacher should make students understand about tenses which are used to make them able to make a sentence because tenses are a verb form that is used in a specific time. So, it must be mastered by the students. According to Lado, tense is the form of the verb that refers to change the time.

The simple present tense refers to action or situation that to do not change frequently. It is used to described habits or routines, to express opinions, or to make general statements of fact, the simple present can also be used to refer to the future. In English grammar, a simple present tense is a form of the verb that refers to an action or event that is ongoing or that regularly takes place in present time (for example "He cries easily").

The simple present tense is the one which we use when an action is happening right now, or when it happens regularly ( or unceasingly, which is why it's sometimes called present indefinite). The simple present tense is formed by using the root form or by adding $-\mathrm{s}$ or $-\mathrm{es}$ to the end depending on the person. Use the simple present tense to express the idea that an action is repeated or usual. The action can be a habit, a hobby, a daily event, a scheduled event or something that often happens. It can also be something a person forgets or usually does not do. Examples:

1. The trains leaves every morning at $08.00 \mathrm{AM}$

2. The trais does not leave at 09.00 AM.

3. When does the train usually leave?

4. She always forgets her purse.

5. He never forgets his wallet.

The simple present can also indicate that the speaker believes that a fact was true before; it is true now and will be true in the future. It is not important if the speaker is correct about the fact. It is also used to generalize people or things.

Examples:

1. Cats like milk

2. Birds do not like milk

3. California is in America

4. California is not in the United Kingdom 
5. Windows are made of glass

Speaker occasionally uses simple present tense to talk about scheduled events in the near future. This is most commonly done when talking about public transportation, but it can be used with other scheduled events as well.

Examples:

1. The trains leaves tonight at 09.00 $\mathrm{AM}$

2. The bus does not arrive at 11 AM. It arrives at $11 \mathrm{PM}$

3. When do we board the plane?

4. The party starts at 08.00 o'clock

5. When does class begin tomorrow?

Speakers sometimes use the simple present tense to express the idea that an action is happening or is not happening now. This can only be done with Non-Continous Verbs or certain Mixed Verbs.

Example:

1. I am here now

2. She is not here now

3. He needs help right now

4. He does not need help now

5. He has his passport in his hands

6. Do you have your passport with you?
The following forms of simple present tense are:

a. Verbal

When the predicate is a verb, the sentence will be called "Verbal sentence"

1. Positive form

$\underline{S+\operatorname{Verb}(s / e s)+O}$

Examples:

My father reads a newspaper every morning.

I get up at 05.00 o'clock.

2. Negative form

$\underline{S+D o / D o e s}+\mathrm{Not}+\mathrm{Verb}+\mathrm{O}$ Examples:

My father does not read a newspaper every morning.

I don't get up at 05.00 o'clock every day

3. Interrogative form

$\underline{D o / D o e s}+S+V 1+O ?$

Examples:

Does my father read a newspaper every morning?

Do you get up at 05.00 o'clock every day?

b. Nominal

When a predicate (in a sentence) is a noun, pronoun, noun phrase, adjective or adverb, the sentence 
will be called "Nominal Sentence”.

1. Positive Form

$\underline{\text { S+To be (is, am, are })+ \text { Noun/ }}$

Pronoun/Adjective

Examples:

The world is round.

Tom and I are students.

2. Negative Forms

$\underline{S+T o b e}($ is, am,are $)+N o t+$

Noun/Pronoun/Adjective

Examples:

My bed is not comfortable.

She is not a teacher.

3. Interrogative Form

$\underline{\text { To be }(i s, \text { am, are })+S+N o u n /}$

Pronoun/Adjective

Examples:

Is your parent at home?

Are these hotels expensive?

There is "time signal" that used in Simple Present Tense. Time signals are words and phrases that tell us when an event takes place. Time signals for the present tense identify more than just one event. Remember that simple present tense is used for repeated events. a. Adverb of time

\begin{tabular}{|c|c|c|c|}
\hline $\begin{array}{c}\text { Every } \\
\text { day }\end{array}$ & $\begin{array}{c}\text { Every } \\
\text { month }\end{array}$ & $\begin{array}{c}\text { Every } \\
\text { week }\end{array}$ & $\begin{array}{c}\text { Every } \\
\text { year }\end{array}$ \\
\hline $\begin{array}{c}\text { Every/ } \\
\text { each }\end{array}$ & $\begin{array}{c}\text { In the } \\
\text { morning }\end{array}$ & $\begin{array}{c}\text { Once/twice } \\
\text { a day }\end{array}$ & $\begin{array}{c}\text { Here/ } \\
\text { there }\end{array}$ \\
\hline
\end{tabular}

Note: adverb of time used in the

first sentence or end of a sentence

Examples:

You write a letter every day.

You do not write a letter every month.

Do you go to the market every week?

b. Adverb of Frequency

\begin{tabular}{|l|l|l|}
\hline Always & Never & Seldom \\
\hline Often & Now & Sometimes \\
\hline
\end{tabular}

Note: adverb of frequency is often

used before the verb or after the verb

Examples:

They usually study English.

They do not always study English.

Do they seldom study English?

Based on the statement above we can conclude that the simple present tense is a sentence construction which tells or shows the daily activities and general truth in the nominal or verbal form of positive, negative, interrogative, and negative sentence using its particular time signals. 


\section{METHOD}

This research is designed by using mixed methods, both qualitative and quantitative. According to Tashakkori \& Teddlie (2008, p.22) as cited in Terrell (2012) states mixed methodology is the study that combines two methods between qualitative and quantitative within use dissimilar stages of the research process. Furthermore, Hyland (2003) claims that combining both quantitative and qualitative methods will gain complete result of research. Additionally, Hyland (2003) also claims "There are, in fact, good reasons for incorporating several techniques in data gathering, and the concept of triangulation, the use of multiple sources, provides for greater plausibility in interpreting results".

\section{FINDING AND DISCUSSION}

In this chapter presents the analysis of students' writing products in using present tense in writing descriptive text and the questionnaire. Moreover, this chapter elaborates the findings on the students' errors in their writing products and the questionnaire. The students' writing products concerning the students' errors in using the present tense in writing descriptive text and the questionnaire will describe the factors causing the students' skill in writing descriptive text. The data were analyzed to answer the research questions, as stated before.

Based on the study that was conducted at STISIP Persada Bunda Pekanbaru, the researcher found some results of students' errors in using the present tense in writing descriptive text. After collecting and identifying the data, the researcher explained them in detail. First, the researcher identified and then classified the errors into four types; Omission, addition, misordering and misformation. Next, these errors were analyzed and summarized in the form of a table. The total of errors was presented in the form of a table in order to answer the first research question about the most dominant students' errors in using the present tense in writing descriptive text.

\section{Omission}

After analyzing the students' writing products based on surface strategy taxonomy. In their writing 
products, the researcher found many errors of Omission. Most of them did not add 's' or 'es' after using a third singular person (she, he, and it), did not contribute the articles ( $a$, an and the) before using a noun, and did not use to be (is, am, and are) before an adjective, etc. Moreover, the errors of Omission the examples:

Errors made by students:

a) The boy always eat in my room

b) She sing with me

c) We take to many book

\section{Suggested corrections:}

a) The cat always eats in my room

b) She sings to play with me

c) We take too many books

Based on the examples, the students did not add suffix 's' that should appear in using third singular person and plural noun. Omission errors happened when the learners did not contribute to the critical item that should be written. These errors happened because, in Indonesia, the subject did not change the verb and did not require to add $\mathrm{s}$ or es in using a plural noun.

\section{Errors made by students:}

a) I so sad to stay in this city

b) I can with family c) It bigger than my cat

\section{Suggested Corrections:}

a) I am so sad to stay in my bedroom

b) I can be with family

c) It is bigger than my cat

Another omission also happened due to the students did not put to be (is, am, and are) before using adjective and adverb and they did not use the main verb after using a modal auxiliary verb (can, must, and have to). According to the sentences, there were found some errors in their writing product.

\section{Students' Errors:}

a) She like learn France

b) I want with my mother forever

c) His father job is a driver

\section{Suggested Corrections:}

a) She likes to learn France

b) I want to be with my mother forever

c) Her father's job is a driver

There were some errors in this omission types which was presented in the table. These errors happened due to the students who did not use to-infinitive after using word want and like. The other Omission of errors was that the students did not use 's' in 
showing the possessive and did not use the base word after using toinfinitive.

Omission errors happened when the learners did not contribute to the critical item that should be written in the sentence. According to the table, most of the students did not add 's' or 'es' when they used the third person singular and the plural noun. Additionally, they also still confused to differentiate between verb and adjective. The omission errors occurred due to the differences between Indonesian structure and English. In Indonesian, the subject did not change the verb, and the adjective did not need an auxiliary verb, etc. Based on those problems, the errors appeared in their writing products. Therefore, the students should pay attention to the crucial items that should appear in English writing in order to avoid grammatical errors and to construct good writing.

\section{Addition}

After analyzing the 12 students' writing products, the researcher found some errors of addition. The sample of sentences are:

\section{Students' Errors:}

a) I am is the most dilligent

b) Dilla and Rania is wear new hat

c) She always singing for me

\section{Suggested Correction:}

a) I am the most dilligent

b) Dilla and Rania are wearing new hat

c) She always sings for me

The examples above represented the other examples of students' errors in using the present tense in writing descriptive text. Addition happened when the learners used the unwanted items. These errors happened since they had obtained inadequate rules of English. Thus, they just applied the rules that they had already known in writing the sentences by using the present tense. Meant, they only knew that to be (is, am, and are) was necessary, but they did not know when it was required. Therefore, they had to learn more about the

English rule in order to minimize those errors. 


\section{Misordering}

\section{Students' Errors:}

a) $\mathrm{He}$ is a girl beautiful

b) She has a long hair, her hair is brown

c) She likes learn language France

\section{Suggested correction:}

a) She is a beautiful girl

b) She has a long and brown hair

c) She likes to learn France language

In this category of errors, the students made errors in their writing products. They wrote the sentences in the incorrect placement which based on Indonesian pattern. These errors happened due to they just translated the word from Indonesian to the English pattern. Means, they were still familiar with their first language structure.

\section{Misformation}

After the researcher identifying and classifying the errors based on surface strategy taxonomy, the researcher found students' errors in misformation.

\section{The three examples of misformation:}

a) I can be with they tomorrow

b) There is many boys in park

c) It is a fat and short body

\section{Suggested Correction:}

a) I can be with them tomorrow

b) There are many boys in park

c) It has a fat and short body

Based on the examples above, misformation errors occurred when the learners used wrong to be (is, am, and are), pronoun, auxiliary verb (have or has). The students tended to make the errors since they do not use the correct form of tobe, auxiliary verb, and pronoun. Most of the students were still challenging to use the right to be (is, am, and are) based on subject, and they were difficult to differentiate between subject and object pronoun. If they used the plural noun, they had to contribute the appropriate tobe on it.

Therefore, in English, the subject would determine the verb or the auxiliary verb. Moreover, the students tended to make this error because they just obtained some English rules, but they were hard to 
decide whether the items were appropriate or not.

The questionnaire was distributed to the students on the first semester of STISIP Persada Bunda Pekanbaru. The analysis of this data would be highlighted to the second research question, which aimed to describe the factors causing students' errors in using the present tense in writing descriptive text.

After analyzing the data collection; students' writing products in using present tense in writing descriptive text and questionnaire were necessary to discuss the result of this study. The purposes of this study were to find out the answer to the research questions. Furthermore, this study aimed to identify the most dominant errors and to describe the factors causing the students' errors in using the present tense in writing descriptive text. Thus, the first research question was "What are the most dominant errors made by the first semester students in using present tense in writing the descriptive text?". Thus, the first discussion would focus on the analysis of students' writing products using the present tense in writing descriptive text. This stage was to find out the types of error and identified the most dominant students' errors in using present tense in writing descriptive text based on surface strategy taxonomy (Omission, addition, misordering and misformation). In this study, the researcher analyzed the 12 students' writing products in using present tense in writing descriptive text.

Thus, the first research question was "What are the most dominant errors made by the secondgrade students in using present tense in writing the descriptive text?". Thus, the first discussion would focus on the analysis of students' writing products using the present tense in writing descriptive text. This stage was to find out the types of error and identified the most dominant students' errors in using present tense in writing descriptive text based on surface strategy taxonomy (Omission, addition, misordering and misformation). In this study, the researcher analyzed the 12 students' writing products in using present tense in writing descriptive text. 
In conclusion, based on analyzing the 12 students' writing products in using present tense in writing descriptive text, the researcher found several errors that were made by the first semester students of STISIP Persada Bunda Pekanbaru. Thus, after analyzing and calculating the errors were found 18 $(20,22 \%)$ omission, $12 \quad(13,48 \%)$ addition, $3(3,37 \%)$ misordering, and 56 $(62,92 \%)$ misformation. According to the result, the total of all errors in this study which classified the errors into four categories (Omission, addition, misordering and misformation) were 89 errors. In this section, the first research question had been answered through the result of students' writing products. Thus, the most dominant errors in using present tense in writing descriptive text made by the first semester students of STISIP Persada Bunda Pekanbaru was misformation, which was found $56(62,92 \%)$ items.
Tabel 1 The Results of Students'

\begin{tabular}{|c|c|c|c|}
\hline \multicolumn{4}{|c|}{ Test } \\
\hline No & $\begin{array}{c}\text { Types of } \\
\text { Errors }\end{array}$ & $\begin{array}{c}\text { Total } \\
\text { of } \\
\text { Errors }\end{array}$ & Percentage \\
\hline 1. & Omission & 18 & $20,22 \%$ \\
\hline 2. & Addition & 12 & $13,48 \%$ \\
\hline 3. & Misordering & 3 & $3,37 \%$ \\
\hline 4. & Misformation & 56 & $62,92 \%$ \\
\hline & Total & 89 & $100 \%$ \\
\hline
\end{tabular}

The table above showed the total of students' errors in using the present tense in writing descriptive text. As was presented in the table, most of the students omitted the essential items in the sentences. Most of them did not use to be (is, am, and are), auxiliary verb (have and has), the article ( $a$, an, and the), etc. Thus, the highest error was misformation, which they made 56 errors $(62,92 \%)$. Meanwhile, the students made 12 $(13,48 \%)$ errors of addition, 3 $(3,37 \%)$ errors of misordering, and 18 $(20,22 \%)$ errors of Omission. Therefore, several errors were 89 errors in using the present tense in writing descriptive text. 


\section{CONCLUSION}

In this section, the writer would like to give a conclusion and suggestion about the result of the study. The conclusion of the study was the answer to the problem, as stated, which the finding was based on the result of the data analysis. The suggestions are expected to make better improvement and motivation for students, teachers and the next researchers. So, almost of the students are good at writing a short paragraph by using the simple present tense. Concerned with the conclusion, the writer would like to propose some suggestions that hopefully would be useful and valuable for the first semester students of STISIP Persada Bunda Pekanbaru. The writer recommended the students to learn more in writing, especially in functional writing, because it will help the students infill the purpose of their assignment and their language skill in future.

\section{REFERENCES}

Arikunto, Suharsimi. (2006). Prosedur Penelitian: Suatu pendekatan Praktek. Jakarta: PT Rineka Cipta.

Arvani, Mansour., and Tabriz. (2006). "A Discourse Analysis of Business Letters Written By Iranians \& Native Speakers." The Asian ESP Journal, June Vol.1. Article 2.

Ary, Donal., et al. (2010). Introduction to Research in Education. Wadsworth.

Brown, Douglas H. (2010). Principles of Language Learning and Teaching Fourth Edition, New York: Longman Inc.

Brown, Douglas H. Teaching by Principles: an Interactive Approach to Language Pedagogy (2 $\left.{ }^{\text {nd }} E d\right)$ : Longman.

Burdová, Veronika. (2007). English for Specific Purposes (Tourist Management and Hotel Industry). Masaryk University Faculty of Education Department of English Language and Literature.

Carey, John A. (2002). Business Letter for Busy People, 4th Edition. The Caree Press, USA.

D, Gould. E. et.al. (1989). The Act of Writing, New York: Random House. 
Dierkes, Meinolf; Hans Weiler and Ariane Antal. (1987). Comparative Policy Research. Gower.

Donn, Byrne. (1979). Teaching Writing Skill. England: Long Man.

Dulay, Heidi., et al. (1982). Language Two. New york: oxford university press.

Fauziati, Endang. (2002). Teaching English as a Foreign Language. Surakarta: Muhammadiyah University Press.

George E. Whison and Julia M. Burks._. Let's Write English Revised Edition, Van Nostrand Reinhold Ltd.

Harmer, Jeremy. (2007). How to Teach Writing. England: Longman.

Herlina. (2012). "The Effectiveness Of Using Concept Mapping In Writing Recount Paragraph Toward The Students' Writing Ability At The Tenth Year Of Sma Muhammadiyah 1 Tumbang Samba Katingan Tengah." State Islamic college of Palangka Raya Department of Education Study Program of English Education. 